\title{
STAGNANT ICE AT THE BED OF WHITE GLACIER, AXEL HEIBERG ISLAND, N.W.T., CANADA
}

\author{
by
}

Heinz Blatter

(Department of Geography, Swiss Federal Institute of Technology, Zürich, Switzerland)

\begin{abstract}
A total of 400 soundings along 15 profiles were obtained on White Glacier, Axel Heiberg Island, N.W.T. with a monopulse radar equipment that was rebuilt according to a model of the US Geological Survey. The resulting data allowed maps to be compiled of the ice thickness for the glacier tongue. The radio echo-sounding data and englacial temperature measurements give some indication of the existence of stagnant ice in depressions of the glacier bed in the accumulation zone of White Glacier.
\end{abstract}

\section{INTRODUCTION}

Since 1959 glaciological and climatological data have been collected on the White Glacier, Axel Heiberg Island, N.W.T., Canada, by members of the McGill-Axel Heiberg Island Research Expedition of the late Professor F. Müller. In the first years, the main studies focused on mass balance (Müller 1963[a]), shallow depth ice temperature measurements (Müller 1963[b]) and the study of ice movement and fluctuations (Iken 1974). On 3 transverse profiles, ice thickness measurements with seismic (Redpath, 1965 ) and gravimetric (Becker 1963) soundings were made.

In the years 1974 to 1981 , vertical profiles of the ice temperatures were measured at 32 sites, some reaching close to bedrock (Blatter 1985). A more detailed and accurate picture of the bedrock topography was gained by radio echo-sounding in May 1984.

White Glacier is a valley glacier situated at altitudes ranging from 80 to $1600 \mathrm{~m}$ a.s.l. with a correspondingly wide range of conditions. The mass balance, for example, varies from about $-2.5 \mathrm{~m}$ water equivalent on the lowest part of the tongue area to about $+0.4 \mathrm{~m}$. w.e. in the higher parts. The mean annual temperature of the glacier is around $-18^{\circ} \mathrm{C}$; the annual precipitation is $170 \mathrm{~mm}$, mainly falling during the spring and summer season. The melt season starts in June with strong radiation and usually ends in mid-August. However, the year-to-year variations may be rather high with the equilibrium line varying between $400 \mathrm{~m}$ and $1500 \mathrm{~m}$ a.s.l. and the mean altitude being at around $1100 \mathrm{~m}$ a.s.l. The glacier is cold except for a layer which is up to $40 \mathrm{~m}$ thick near the bedrock in the lowest tongue area (Blatter 1985). The surface ice velocities are up to $40 \mathrm{~m} \mathrm{a}^{-1}$ in the central part of the glacier. During strong melt events or periods of rainfall, peak velocities may be up to 5 times faster than the mean annual value.

\section{DEPTH SOUNDING}

For the sounding campaign on the White Glacier, the US Geological Survey Monopulse Ice Radar (Watts and England 1976; Hodge unpublished; Watts and Wright 1981) was used. The equipment was partly built with the help of the Laboratory for Hydraulics, Hydrology and Glaciology at the Swiss Federal Institute of Technology, Zürich (Haeberli and others 1983).

The operating equipment consists of a transmitter and a receiver placed about $50 \mathrm{~m}$ apart on the glacier surface, both equipped with identical, resistively loaded, centre-fed dipole antennas. The antenna arms used were $20 \mathrm{~m}$ long, which gives the choice of $10 \mathrm{MHz}$ radio frequency. The transmitter works with avalanching transistors, giving a pulse repetition rate of about $10 \mathrm{kHz}$ (Hodge unpublished). The signal from the receiver antenna is fed directly into a battery-powered oscilloscope. The direct signal from the transmitter and the reflected signal from the glacier bottom are displayed on the screen, where the difference of the transmission time of the signals can be read to an accuracy of a $1 / 100 \mu \mathrm{s}$. The equipment allowed identification of reflected signals to a depth of $500 \mathrm{~m}$. Soundings of glacier thicknesses of less than $50 \mathrm{~m}$ proved to be unsatisfactory. This may be caused by the length of the antenna which records a diffuse transmission time due to diffuse path lengths.

The sounding profiles were chosen transverse to the valley axis and the antennas were laid out orthogonal to the profile direction on the ice surface. The equipment, including theodolite and laser distomat for surveying the sounding locations, weighed less than $100 \mathrm{~kg}$ and could be handled and operated by three people.

\section{BEDROCK TOPOGRAPHY}

The evaluation of the sounding data was perfomed by direct geometrical means. It was assumed that the reflection points lie within the vertical plane of the surface profile. The possible locations for the reflection points, the ellipse with the focal points at the transmitter and at the receiver station could be closely approximated by circles for ice thicknesses of more than $100 \mathrm{~m}$. The envelope of the circles of one profile is then assumed to give an upper limit to the elevation of the glacier bed, as is illustrated for example in Figs 3, 4, and 5.

The velocity of the radio waves in ice was chosen at $168 \mathrm{~m} / \mu \mathrm{s}$ (Robin 1975, Glen and Paren 1975). The same value was used for firn and the refraction was neglected (Rasmussen 1986). Since firn layers are usually about $50 \mathrm{~m}$ thick, this error is negligible in the order of the reading accuracy. Finally, it is believed that the relative accuracy of the depth sounding is about 5 to $10 \%$ (Haeberli and Fisch 1984), owing to the uncertainty of wave velocity, transmission time reading, and the location of the reflection point at the bedrock.

The above method proved to work very well in the tongue area of the glacier where the bedrock forms a simple U-shaped valley. Usually, the radar soundings confirmed drilling depths within the limits of accuracy. On the other hand, the results obtained from earlier seismic soundings (Redpath 1965) and gravimetric soundings (Becker 1963) now show substantial differences (sometimes by as much as $50 \%$ ) from the radar sounding thicknesses.

The data from 11 transverse sounding profiles have enabled compilation of a map of the glacier bed topography and thus for the glacier thickness in the tongue area (Fig.1), although smaller features $(<50 \mathrm{~m}$ in the horizontal) of the bedrock cannot be spatially resolved.

The soundings performed in the acumulation zone, however, frequently produced multiple echoes. To explain 


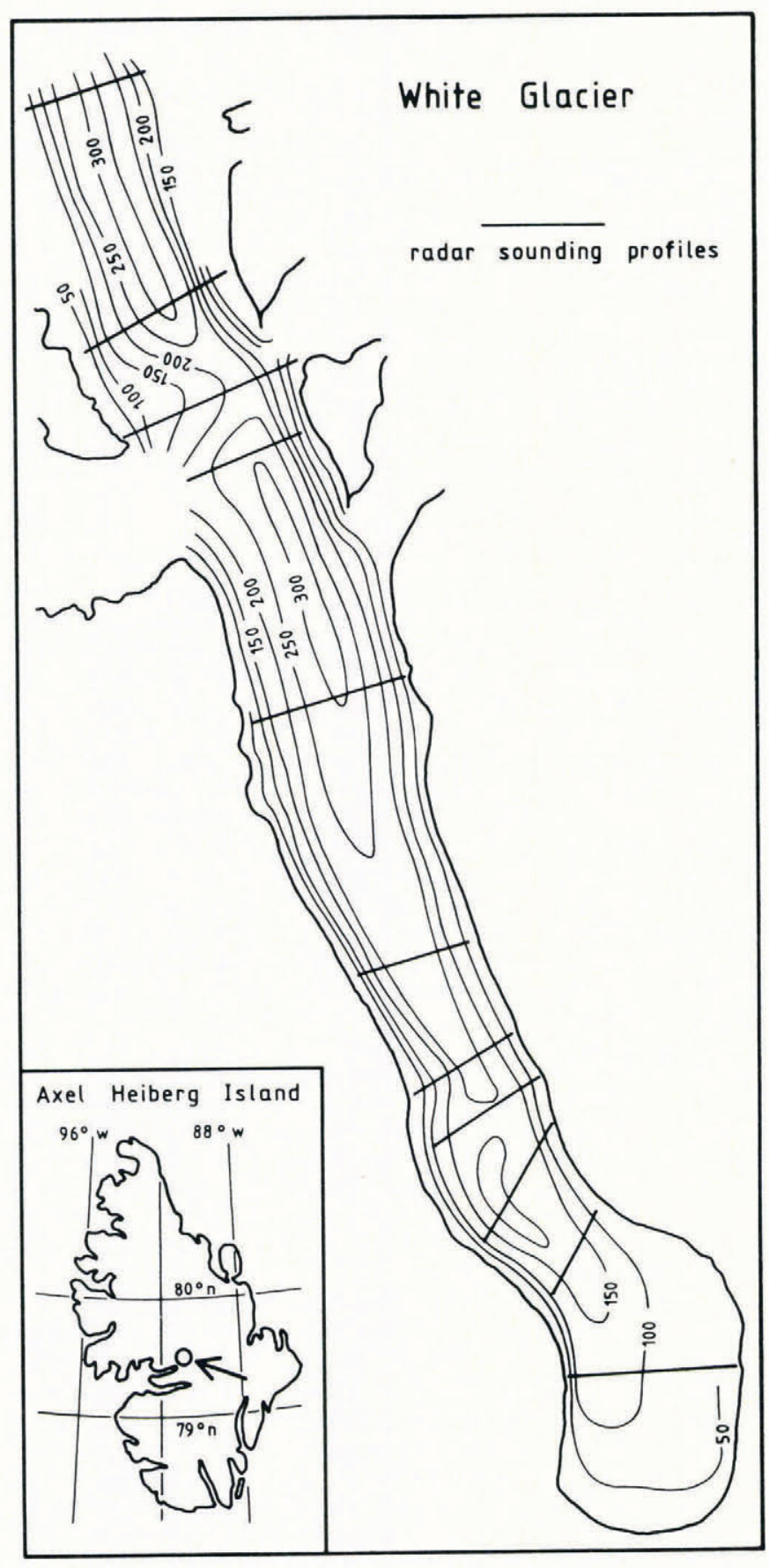

Fig.1. Map of the ice thickness in the tongue area of White Glacier with an inset map of Axel Heiberg Island.

those, additional information on the glacier and on the valley topography is needed.

A first indication for a rather irregular or uneven bedrock topography is given by the various rock ridges reaching into the glacier area that are partly visible from the glacier surface topography. Some transverse sounding profiles also reveal a relatively deep valley leading from the highest part down the centreline of the glacier accumulation basin. The locations of these profiles are given in Fig. 2 and one example illustrating the transverse profile at the Beaver Profile shows the channel-like feature in the upper part of the glacier bed (Fig.3).

\section{ENGLACIAL TEMPERATURE PROFILES}

In the years from 1974 to 1981 , a total of 32 holes was drilled on White Glacier (Blatter 1985). An open-system hot-water drill fed from a melt-water river or from water-filled plastic pools was used to melt the holes in the

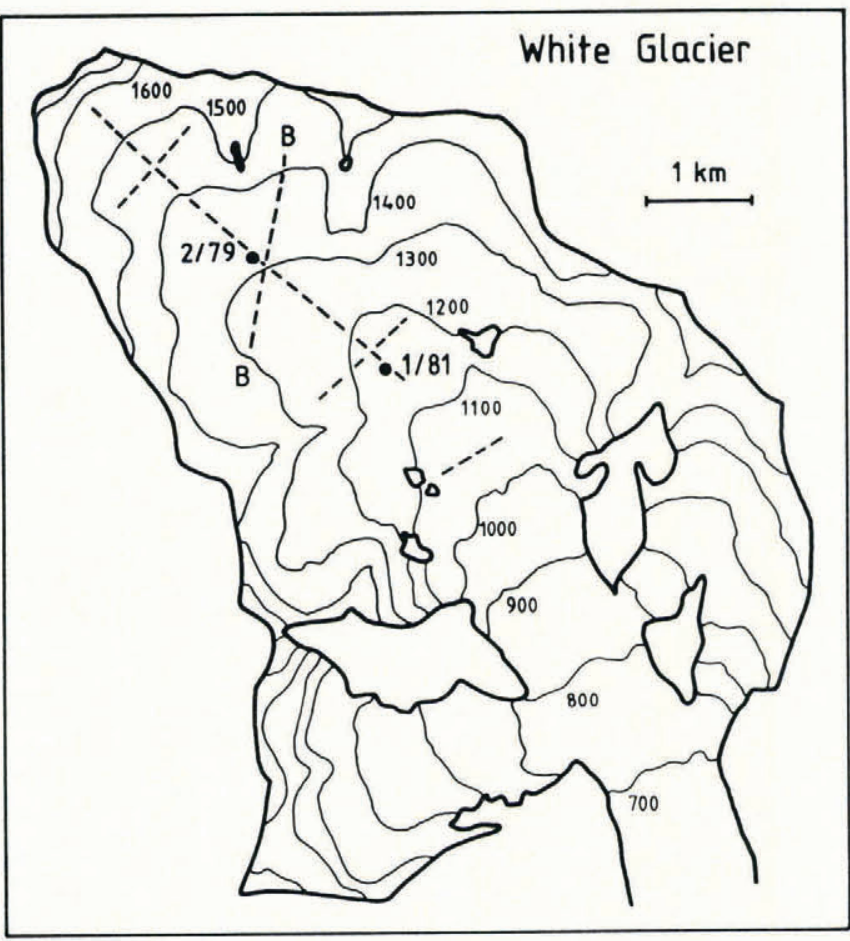

Fig.2. White Glacier accumulation area showing the surface topography, the location of drilling sites (labelled dots) and of the sounding profiles (dashed lines) (B----B indicates the transverse Beaver Profile).

glacier ice (Iken and others 1977). The drilling equipment could be handled and operated by three people. The deepest hole had a depth of $380 \mathrm{~m}$ and was drilled in about 6 hours. At the end of the drilling, a multi-core cable with a series of thermistors was inserted in the hole while it was still filled with water. The holes were usually frozen within 12 hours of the end of the drilling and the temperatures reached equilibrium after 3 weeks within the possible reading accuracy. This was confirmed for many data samples by repeated measurements during the adjustment period and even re-readings of the temperatures a year later. The readings were performed with a resistance bridge which proved to be quite reliable, since the voltage compensation showed little temperature dependence. The estimated accuracy of the temperature readings was $\pm 0.2^{\circ}$, which is confirmed by the smoothness of measured profiles. This allows for an accuracy of better than $\pm 0.005 \mathrm{~K} \mathrm{~m}^{-1}$ for the temperature gradient if determined by 4 to 5 thermistors over a vertical distance of about $50 \mathrm{~m}$ thick.

In the U-shaped valley, the drilling depth usually lies within the 5 to $10 \%$ accuracy range of the radar sounding depth. Radio soundings also seem to underestimate the ice thickness, an observation which was also reported by Haeberli and Fisch (1984). However, at site $2 / 79$ in the accumulation zone (Fig.2), the measured temperature profile was $350 \mathrm{~m}$ long and reached $25 \mathrm{~m}$ deeper than the deepest soundings and $100 \mathrm{~m}$ deeper than the most shallow sounding.

Several explanations of these differences are possible. First, a reflecting debris layer above the glacier bed can most likely be excluded. Some medial moraines in the tongue part of the glacier can be traced back to their origins. Otherwise, the glacier surface gives no indication of an extended debris content in the ice and the surrounding snow ridges give no hints of sources of debris in the highest parts of the glacier. The drilling was sometimes stopped before reaching the glacier bed, presumably because of meeting rocks within the ice, but only at sites where there was also debris on the surface. Secondly, a sharp turn in the direction of the drill hole could explain both the thickness difference and the sudden increase in the measured temperature gradients. Such abrupt changes occurred on rare occasions during drilling in Swiss Alpine 


\section{White Glacier}

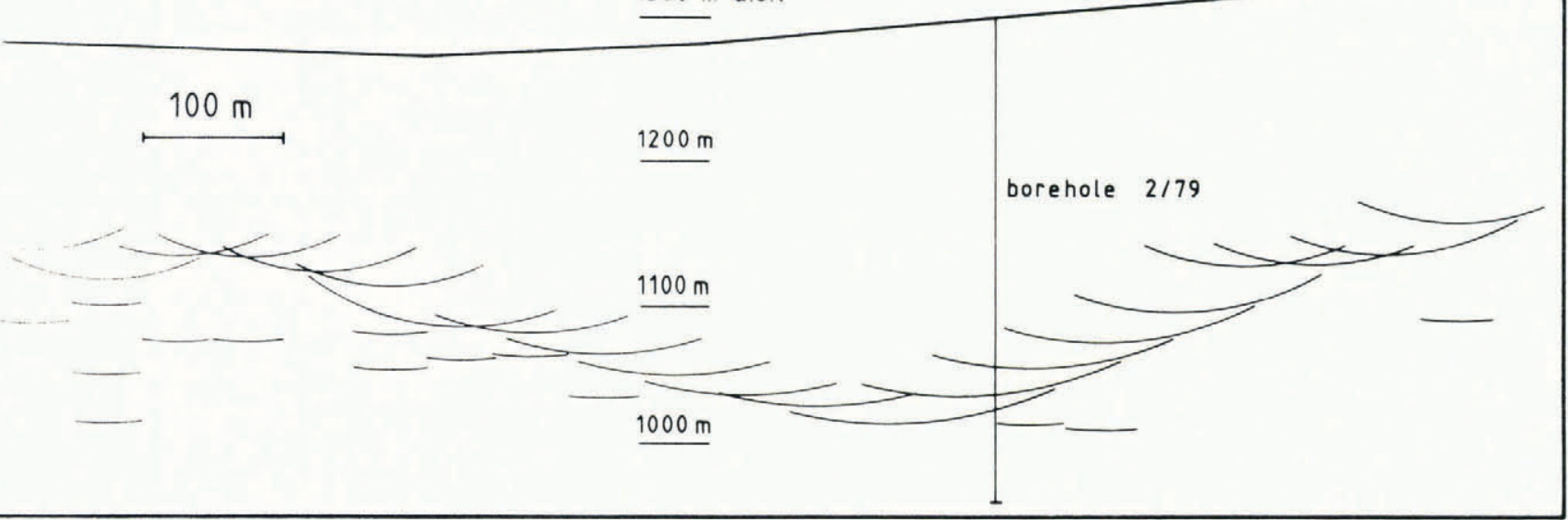

Fig.3. Radar sounding depth profile at the transverse Beaver Profile (B----B in Figure 2).

glaciers (Röthlisberger, personal communication). To explain this change in the measured temperature gradient at site $2 / 79$, the bend in the drill hole would have to be $60^{\circ}$, which is rather unlikely.

It also seems unlikely that the drilling did not reach the depth as indicated by the length of the drilling hose hanging in the hole. It was usually possible to feel whether the drill was advancing or not. Since the drilling hose is rather stiff, it also seems unlikely that it became coiled in the lower part of the hole. There, the diameter of the hole is only about twice as large as that of the hose.

A third factor relates to the englacial temperature measurements. About $60 \mathrm{~m}$ above the bottom of the drilling, the temperature profile shows an abrupt bend (Fig.4), giving a temperature gradient of $0.011 \pm 0.005 \mathrm{~K}$ $\mathrm{m}^{-1}$ below and $0.032 \pm 0.005 \mathrm{~K} \mathrm{~m}^{-1}$ above that level. The lower value seems to correspond to a geothermal heat flux of around $0.023 \mathrm{~W} \mathrm{~m}^{-2}$, which is a very low value when compared with reported values of 0.05 to $0.08 \mathrm{~W} \mathrm{~m}^{-2}$ for this region (Judge 1973). However, all vertical ice temperature profiles reaching close to bedrock in the accumulation area show temperature gradients of the order of 0.02 to $0.032 \mathrm{~K} \mathrm{~m}^{-1}$. This indicates a small local geothermal heat flux since these gradients also contain part

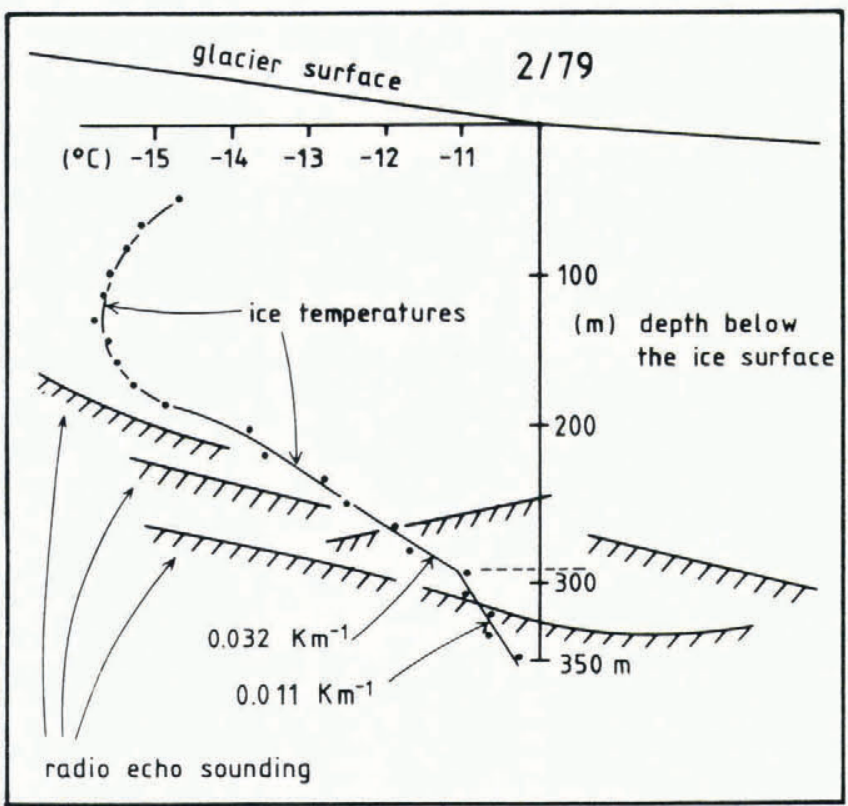

Fig.4. Comparison of the drilling depth and the radar sounding depths around the drilling site $2 / 79$ with the measured temperature profile.

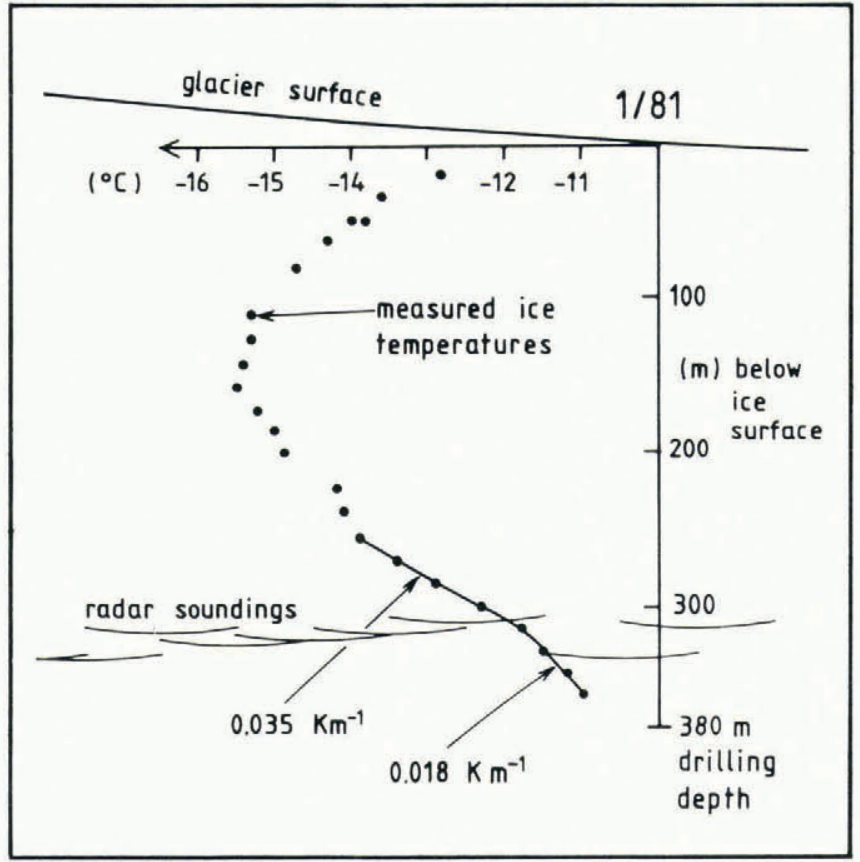

Fig.5. Comparison of the drilling depth and the radar sounding depths around the drilling site $1 / 81$ with the measured temperature profile.

of the differential heat flux. The difference of $0.021 \pm$ $0.007 \mathrm{~K} \mathrm{~m}^{-1}$ can be explained by the heat generated by the differential flow (W) at the level of the change which is given by:

$$
\mathrm{W}=0.4(\mathrm{f} \rho \mathrm{g} \sin \alpha)^{4} \mathrm{Ah}^{5} \quad \text { where }
$$

$f=$ Nye shape factor

$\rho=$ ice density

$\alpha=$ surface slope

$A=$ flow law parameter

$\mathrm{h}=$ ice thickness

This equation is appropriate for a parallel-sided slab model with a flow law exponent of $n=3$. Although it contains the surface velocity from integration of the internal deformation over the whole thickness of the ice, it can be used for estimating the change of the temperature gradient within a relatively small layer of the bottom of the deforming part where most differential heat is released (Blatter 1985). Given the measuring accuracy of the temperatures, any gradient change can be located to a layer of $20-30 \mathrm{~m}$ thickness. 
With the following values substituted into the equation: $\mathrm{f}=0.8, \rho=900 \mathrm{~kg} \mathrm{~m}^{-3}, \sin \alpha=0.08, \quad \mathrm{~A}=5.210^{-25}$ $\mathrm{s}^{-1} \mathrm{~Pa}^{-3}$ (Paterson, 1981) and $\mathrm{h}=290 \mathrm{~m}$ the heat generation $(\mathrm{W})=0.0435 \mathrm{~W} \mathrm{~m}^{-2}$, it may thus be possible to explain the required increase of the temperature gradient of $0.021 \mathrm{~K} \mathrm{~m}^{-1}$. Since most parameters in the equation have high powers (4 and 5 ) the numerical result should be considered an order of magnitude estimation of the heat generation.

The situation is similar at site $1 / 81$ with a temperature gradient of $0.018 \pm 0.005 \mathrm{~K} \mathrm{~m}^{-1}$ below and $0.035 \pm 0.005 \mathrm{~K} \mathrm{~m}^{-1}$ above the bend in the measured temperature profile.

\section{DISCUSSION AND CONCLUSIONS}

Radio echo-sounding with the USGS Monopulse Ice Radar provided rather good results within the possible accuracy for the U-shaped glacier tongue bed. However, in the higher part of the glacier, in an area of a widened valley with several tributaries from the sides, the sounding consistently underestimated the ice thickness when compared with drilling depths by an amount to be explained by other factors.

The combined information of the soundings and the measured temperature profile at site $2 / 79$ with a relatively sharp bend at about the depth given by the radar sounding indicates the possibility of the existence of stagnant ice about $60 \mathrm{~m}$ thick in a depression of the bed below site $2 / 79$. This interpretation is rather speculative owing to the ambiguous sounding data and the accuracy of the temperature measurements of $\pm 0.2 \mathrm{~K}$. However, the same features were observed further down the glacier at site $1 / 81$, although not as clearly as at site $2 / 79$, with a drilling depth of $380 \mathrm{~m}$ and a sounding depth of only 310 to 340 m (Fig.5).

\section{ACKNOWLEDGEMENTS}

All field activities on White Glacier were made possible thanks to the generous logistic support of the Polar Continental Shelf Project, Ottawa, Canada, and the financial support of the Swiss Federal Institute of Technology, Zürich, Switzerland, and McGill University, Montreal, Canada. Dr M Funk, Dr B Ott, and H J Frei did the laborious job of the sounding and $\mathrm{K}$ Schroff built the sounding equipment. Professor A Ohmura encouraged the project with stimulating discussions. $\mathrm{Dr}$ W Haeberli helped with the training on the sounding equipment and the evaluation method.

\section{REFERENCES}

Becker A 1963 Gravity investigations. (Interim Report.) McGill University, Montreal. Axel Heiberg Island Research Reports. Preliminary Report 1961-1962: 97-101

Blatter H 1985 On the thermal regime of Arctic valley glaciers; a study of White Glacier, Axel Heiberg Island, and the Laika Glacier, Coburg Island, Canadian Arctic Archipelago. Zürcher Geographische Schriften 22

Glen J W, Paren J G 1975 The electrical properties of snow and ice. Journal of Glaciology 15(73): 15-38

Haeberli W, Fisch W 1984 Electrical resistivity soundings of glacier beds: a test study on Grubengletscher, Wallis, Swiss Alps. Journal of Glaciology 30(106): 373-376

Haeberli W, Wächter H-P, Schmid W, Sidler C 1983 Erste Erfahrungen mit dem U.S.-Geological-Survey MonopulsRadioecholot im Firn, Eis und Permafrost der Schweizer Alpen. Zeitschrift für Gletscherkunde und Glazialgeologie 19(1): 61-72

Hodge S M Unpublished USGS mono-pulse ice radar. Washington, DC, US Geological Survey (Internal Report)

Iken A 1974 Velocity fluctuations of an Arctic valley glacier; a study of the White Glacier, Axel Heiberg Island, Canadian Arctic Archipelago. McGill University, Montreal. Axel Heiberg Island Research Reports. Glaciology 5

Iken A, Röthlisberger H, Hutter K 1977 Deep drilling with a hot water jet. Zeitschrift für Gletscherkunde und Glazialgeologie 12(2), 1976: 143-156
Judge A 1973 Geothermal measurements in northern Canada. In Aitken J D, Glass D J (eds) GAC-CSPG. Proceedings of the Symposium on the Geology of the Canadian Arctic, Saskatoon, May 1973: 301-311

Müller F 1963[a] Englacial temperature measurements. McGill University, Montreal. Axel Heiberg Island Research Reports. Preliminary Report 1961-1962: 81-89

Müller F 1963[b] Glacier mass budget and climate. McGill University, Montreal. Axel Heiberg Island Research Reports. Preliminary Report 1961-1962: 57-64

Paterson W S B 1981 The physics of glaciers. Second edition. Oxford etc, Pergamon Press

Rasmussen L A 1986 Refraction correction for radio echosounding of ice overlain by firn. Journal of Glaciology 32(111): 192-194

Redpath B B 1965 Seismic investigations of glaciers on Axel Heiberg Island, Canadian Arctic Archipelago. McGill University, Montreal. Axel Heiberg Island Research Reports. Geophysics 1

Robin G de Q 1975 Velocity of radio waves in ice by means of a bore-hole interferometric technique. Journal of Glaciology 15(73): 151-159

Watts R D, England A W 1976 Radio-echo sounding of temperate glaciers: ice properties and sounder design criteria. Journal of Glaciology 17(75): $39-48$

Watts R D, Wright D L 1981 Systems for measuring thickness of temperate and polar ice from the ground or from the air. Journal of Glaciology 27(97): 459-469 